\title{
LOYALTY PROGRAMS IN E-COMMERCE AND THEIR PERCEPTION BY THE YOUNG ADULT INTERNET POPULATION
}

\author{
Tahal, $\mathbf{R}$.
}

One of the topical themes of today's marketing is customer loyalty. There are many tools that can be used to attract a customer and make him loyal. Most frequently applied are special loyalty programs. Some of them are well designed; others are often difficult to understand and they do not bring positive effect. This paper concentrates on e-shop loyalty programs with regard to the young generation of customers. Based on primary data, the goals of e-shops' loyalty programs are compared to the loyalty benefits preferred by customers. Whereas e-shop providers often remunerate their customers on the scheme of cumulative purchase history, customers appreciate an instant reward, regardless of whether it's small or not.

JEL classification: M31

Keywords: loyalty, customer satisfaction, online retail, loyalty program

\section{Introduction}

A frequently discussed topic of today's marketing is customer loyalty. In highly competitive market surroundings, it is very important to understand what type of customers are loyal, why, in what situations, and what are the business conditions that affect the consumers' loyalty. Some of the existing loyalty schemes work well and meet the intentions of their operators; some of them, however, are not well designed and they either result in financial losses or they are too complicated to be understood and accepted by customers.

Companies often build their loyalty schemes without first taking any deep insight into the customers' decision making process. Therefore many loyalty schemes turn into vague marketing communication and even the data they bring are hardly applicable for further development of the company.

Many up-to-date loyalty programs focus on two main goals. The first is to reward the customers who buy either frequently or in high volumes. The second goal is to collect data concerning customers' purchases and to optimize the product offer on this basis. In this connection, the term "Customer Lifetime Value" is used. It means that not only instant purchases should be targeted, but the company ought to take into consideration even the future value, i.e. the potential future purchases by the customer. Another frequently used term that is becoming more and more popular is "Share of Wallet". It describes the situation in the market when a customer is making a choice between two or even more substitute products. The company should try to make its own products the most attractive for the target consumer group and put them in the customer's first choice place.

This paper focuses on the young generation and their on-line purchases. It tries to analyze how this generation evaluates online shopping in the perspective of loyalty programs. Is the effort of e-shop providers effective and does it match with what the young generation really appreciates?

\section{Literature Review}

Although loyal consumers are most typically satisfied, satisfaction does not universally translate into loyalty (Oliver, 1999). Beginning in the 1990s, in large part because of the difficulty with service quality management, many companies shifted their attention to customer retention. Research conducted by the Technical Assistance Research Program in Washington, D.C. found that the primary reason why customers left companies was dissatisfaction caused by such loyalty 
program parameters that do not attract a customer, but on the contrary they may even dissuade him (Zhaohua and Yaobin, 2010). In some e-shops, it is for example the necessity of registration before making a purchase that may block some customers from continuing the purchasing process.

The behavior of Internet users is affected by many factors, e.g. by the characteristics of the Internet population, which can significantly differ from the general population (Stříteský, 2013). There are segments of online shoppers that are very similar to regular shopper groups. To determine this, online shopping motivations on the one hand and e-store attribute importance measures on the other hand are separately used as the basis for developing online shopper typologies. Results reveal that there are more similarities than differences among traditional and online store shoppers (Ganesh et al., 2010). The research conducted for the purpose of this paper concentrates on e-shop customers, their shopping behavior and especially their attitudes toward loyalty schemes.

Loyalty programs of on-line retailers are based on digital solutions. It is very advantageous for them as they can build up a database for email marketing, track preferred customers' birthdays and other special events (Kooser, 2009). In addition to the program's parameters, it is important to know how they are communicated, and which of the aspects are used for branding and positioning. Instead of ,sole brand usage”, loyalty is nowadays defined in terms of ,share of requirements“ or „brand purchased most often“ (Cook, 1996). The effectiveness of the marketing communication is undoubtedly one of the most important issues that marketers and company managers deal with (Tomek, Stříteský and Tahal, 2013).

\section{Methods}

The research target of this paper is to analyze the main features of customer loyalty in electronic commerce and to find out whether, and to what extent, the retailers' and consumers' attitudes meet.

The loyalty program analysis is being made from two points of view. The first one is based on the information gathered in companies that are running their e-shops. The other one is the opinion of those people who can be marked as typical on-line customers.

Both these target groups were questioned using an online method (CAWI). In the case of retailers, initial phone calls have been carried out before sending the questionnaire link in order to increase the response rate.

The assortment of consumers for the purpose of this survey was defined as the young adult Internet population. We interviewed people between 20-29 years of age, representatively covering Prague, as well as the regions of Bohemia and Moravia. The sample size was 159 respondents.

The definition of this survey population is supported by the study of the reputable market research agency STEM/MARK. "Very frequent e-shopping, at least once a week, is done by $8 \%$ of respondents, usually young people (18-29 years) and women. One third of the Internet population do their e-shopping at least once a month. The largest group of the respondents (39\%) use e-shops a couple of times in a year. The elderly and less educated either never or less frequently do electronic shopping" (Šipula, 2013).

The first phase of the survey has been concentrated on e-shop providers. We interviewed thirty-two companies' marketing managers in total. Some of the interviewed companies have been running both brick and mortar branches as well as e-shops; some of them are purely online players. Either way, in this paper we concentrated on the existence or non-existence of a loyalty program in the e-shop; in case of its existence, we asked what are the main objectives of the program and what customer benefits it is based on. Finally, the company manager answered a question about the overall satisfaction with the program, particularly whether it meets expectations.

\section{Results}

\subsection{Aspects of the Loyalty Programs}

The main goal of this section is to answer three research questions concerning retailers' objectives and expectations in connection with the loyalty scheme they have been running.

Research question 1: How do the companies use the data they have gathered in connection with the loyalty program?

When analyzing this topic, it is beneficial to start with the screening process and filter out those companies that haven't implemented either a CRM system or loyalty scheme yet. In the case of our research sample, we filtered out $18.75 \%$. Based on previous studies and surveys, four possible alternatives were defined:

1) Category management and revealing groups of products frequently bought together

2) Portfolio managements and stock optimization

3) Direct marketing - non-customized newsletters and topical information

4) Direct marketing - customized offers and newsletters 
Figure 1 Usage of CRM and loyalty scheme data

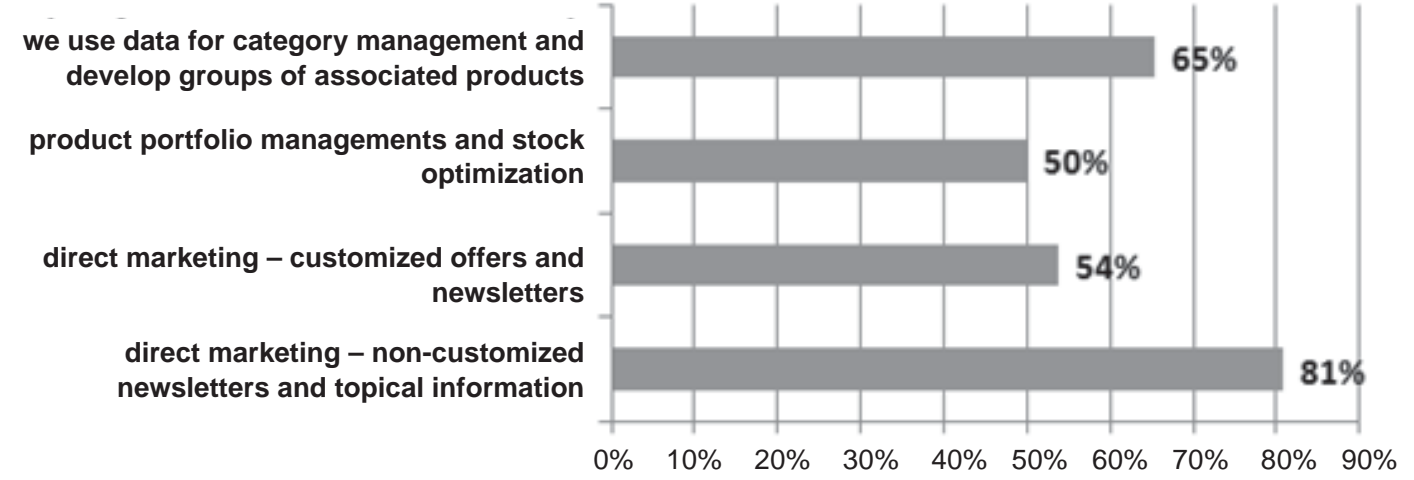

Source: author

Of course, the alternative of "other" was also offered, but no one used it.

An interesting finding is that the group of retailers that develop customized marketing offers "CMO" is a subset of those retailers who send non-customized marketing offers "NCMO".

$$
\text { "CMO" } \subseteq \text { "NCMO" }
$$

Figure 2 Usage of CRM and loyalty scheme data

$100 \%$-retailers who send non customized offers

$76 \%$ - retailers who send customized offers

Source: author

Research question 2: What are the main internal motivators for running a loyalty program?

Further on, our analysis concentrated on the main motivators for the development of loyalty programs. In our questionnaire, a half-closed question (multiple type) offered the shop managers several possibilities of to answer: repeated purchases, turnover increase, profits increase and brand awareness increase. The possibility "other" was also offered, but no one used it.

Loyalty programs are widely understood as the tool for attaching customers to a company. By interpreting the results drawn in the chart above, we can find that retailers aim to persuade customers for repeated purchases and they are aware that implementing a loyalty scheme is a long-term activity and may cause a profit decrease in the close future.

Research question 3: What benefits of the loyal scheme do the companies communicate towards their customers?

The following topic of the survey was to find out how the retailers communicate the benefits of their loyalty program to the customers. It means what loyalty program benefits are those that should attract customers. A half-closed multiple-choice type question was used again. The possible answers were as follows: flat discounts on favorite items, discounts outside your shop (at business partners'), money voucher for the next purchase, instant discount for the purchase, gift (some small item for free),

Figure 3 Company goals in connection with loyalty program

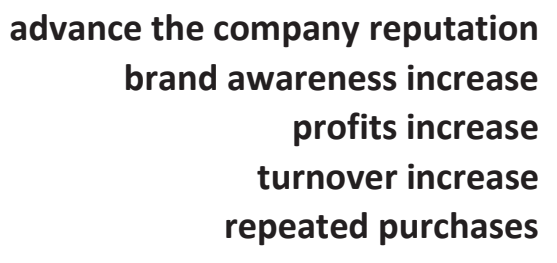

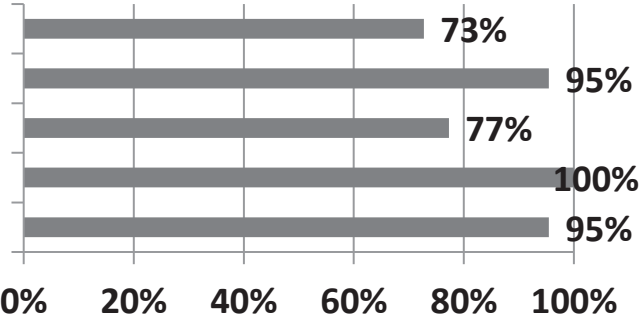

Source: author 
Figure 4 Benefits that retailers communicate to customers

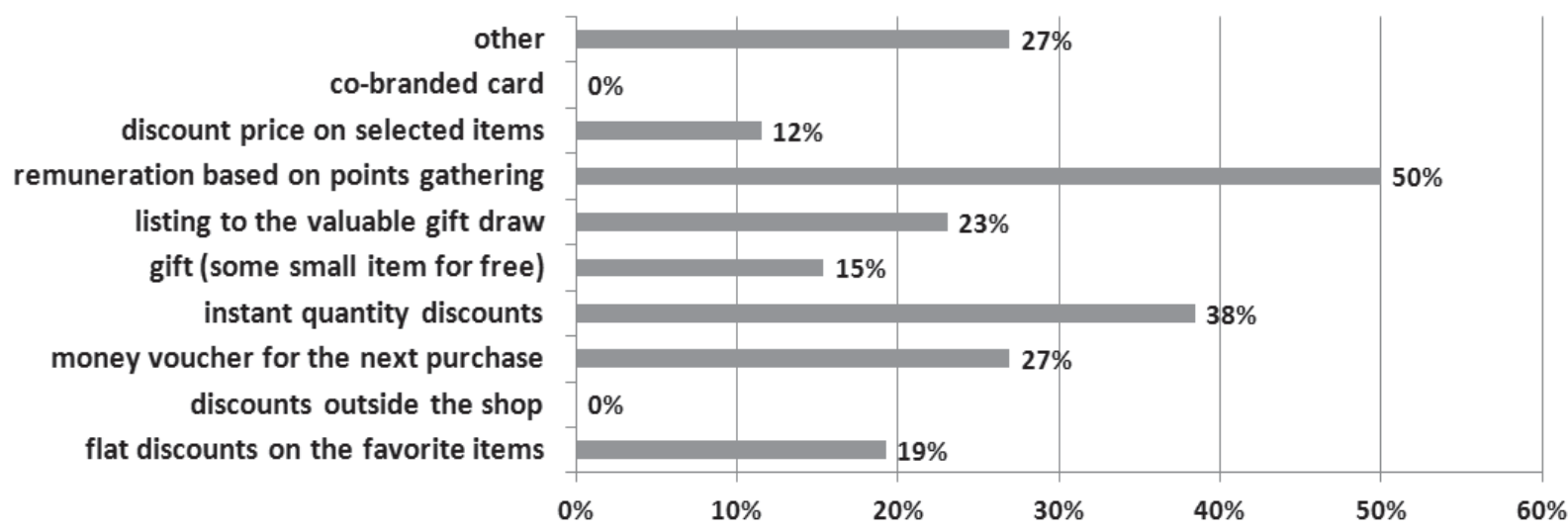

Source: author

listing to the valuable gift draw, remuneration based on points gathering, discount price on selected items, co-branded card, and the "other" possibility.

Among "others" were mentioned premium services like extended possibility of returning non suited goods, or some free of charge extra services.

Finally, the company manager was asked about the overall satisfaction of their company with the existing model of their loyalty program. The respondents were offered the seven point scale, where $1=$ totally unsatisfied and $7=$ fully satisfied. The calculated mean of the satisfaction index was 4.5. This "satisfaction index" was later used for computing the correlation coefficient that should reveal which parameters influence the satisfaction index most strongly.

The next table brings the results. One set of variables is the "satisfaction index"; the other set of variables represents the parameters that influence the satisfaction index with a greater or lesser extent.

From the calculations above, we can specify the significant items for the declared retailers' satisfaction as follows: "using data for category management and developing groups of associated products", "product portfolio managements and stock optimization", "repeated purchases", "discount price on selected items", "instant quantity discounts" and "remuneration based on points gathering".

Table 1 Influence of the way of CRM data using on the overall satisfaction

\begin{tabular}{|l|c|}
\hline Way of using the CRM data & $\begin{array}{c}\text { To what extent does it influence the satisfaction index: } \\
\text { Coefficient }\end{array}$ \\
\hline $\begin{array}{l}\text { using data for category management and developing groups } \\
\text { of associated products }\end{array}$ & 0,71 \\
\hline product portfolio managements and stock optimization & 0,33 \\
\hline direct marketing - non-customized newsletters and topical information & 0,24 \\
\hline direct marketing - customized offers and newsletters & 0,13 \\
\hline
\end{tabular}

Table 2 Influence of the internal company motivators on the overall satisfaction

\begin{tabular}{|l|c|}
\hline $\begin{array}{l}\text { The main internal motivators for running } \\
\text { the loyalty program }\end{array}$ & $\begin{array}{c}\text { To what extent does it influence the satisfaction index: } \\
\text { Coefficient }\end{array}$ \\
\hline repeated purchases & 0,39 \\
\hline brand awareness increase & 0,24 \\
\hline advance of the company reputation & 0,06 \\
\hline turnover increase & $-0,25$ \\
\hline profits increase & $-0,33$ \\
\hline
\end{tabular}

Source: author 
Table 3 Influence of the internal company motivators on the overall satisfaction

\begin{tabular}{|l|c|}
\hline $\begin{array}{l}\text { Benefits of the loyal scheme that are being } \\
\text { communicated to the customers }\end{array}$ & $\begin{array}{c}\text { To what extent does it influence the satisfaction index: } \\
\text { Coefficient }\end{array}$ \\
\hline discount price on selected items & 0,60 \\
\hline instant quantity discounts & 0,44 \\
\hline remuneration based on points gathering & 0,40 \\
\hline flat discounts on favorite items & 0,28 \\
\hline listing to the valuable gift draw & $-0,17$ \\
\hline gift (some small item for free) & $-0,24$ \\
\hline money voucher for the next purchase & $-0,27$ \\
\hline
\end{tabular}

Source: author

\subsection{Customers' Participation in Loyalty Programs}

Besides analyzing the loyalty schemes from the retailers' perspective, the related survey has brought insight into the same issue from the customers' perspective. The screening question of the survey that has been run for this purpose filtered out those respondents who had not made any online shopping during the last six months; $87.4 \%$ respondents met the screening criteria.

This section of the survey concentrated on consumers' participation in any loyalty program run by an e-shop merchandiser and also revealed respondents' perception of loyalty program attributes and what kind of rewards the customers really appreciate.

Research question 4: What is the customers' interest in loyalty programs and to what extent do the customers participate?

When deciding whether to establish a loyalty scheme in the company, it is helpful to measure the business potential of the program. Therefore, we have investigated the extent to which customers like being remunerated for their shopping and consequently whether they have already participated in any program in connection with e-commerce.

Figure 5 Inclination for being remunerated

Do you like being remunerated for on-line shoping?

Source: author

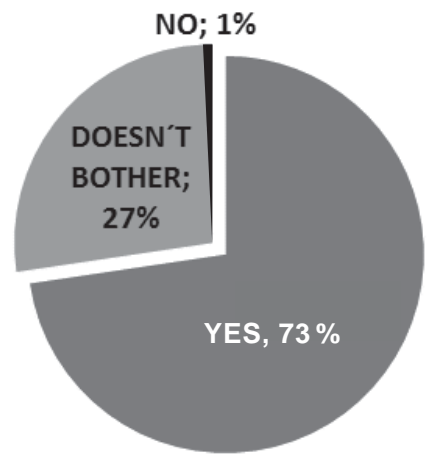

Based on the finding that almost two-thirds of customers like being remunerated, we have investigated whether this potential is already saturated or not.

The survey further revealed that in spite of consumers' preference to be remunerated, only one third (31\% exactly) participate in any program. Therefore, a strong potential for strategic business development can be identified.

\section{Figure 6 Percentage of customers who participate in any} online retailer loyalty program

Are you a member of any e-shop loyalty program?

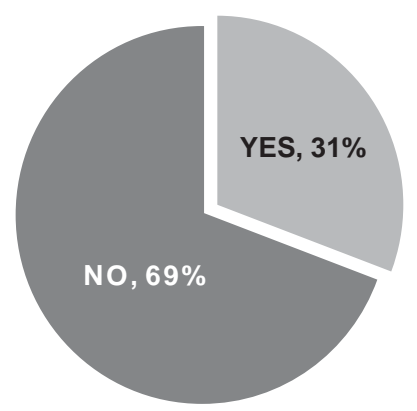

Source: author

\subsection{Comparison of Retailers' and Shoppers' Points of View}

Once a retailer has made the decision to establish a loyalty program, there is the question about what kind of benefit it shall be based on. A very common present-day model is based on gathering and cumulating points based on the value of the purchases done. From a retailer's point of view, it seems to be a logical strategy, because the company tends to motivate customers for repeated purchases. But this model is always based on the necessity of customers' registration in a program. Customers are more or less intensively forced to deliver 


\section{Figure 7 Loyalty benefits communicated vs. preferred}

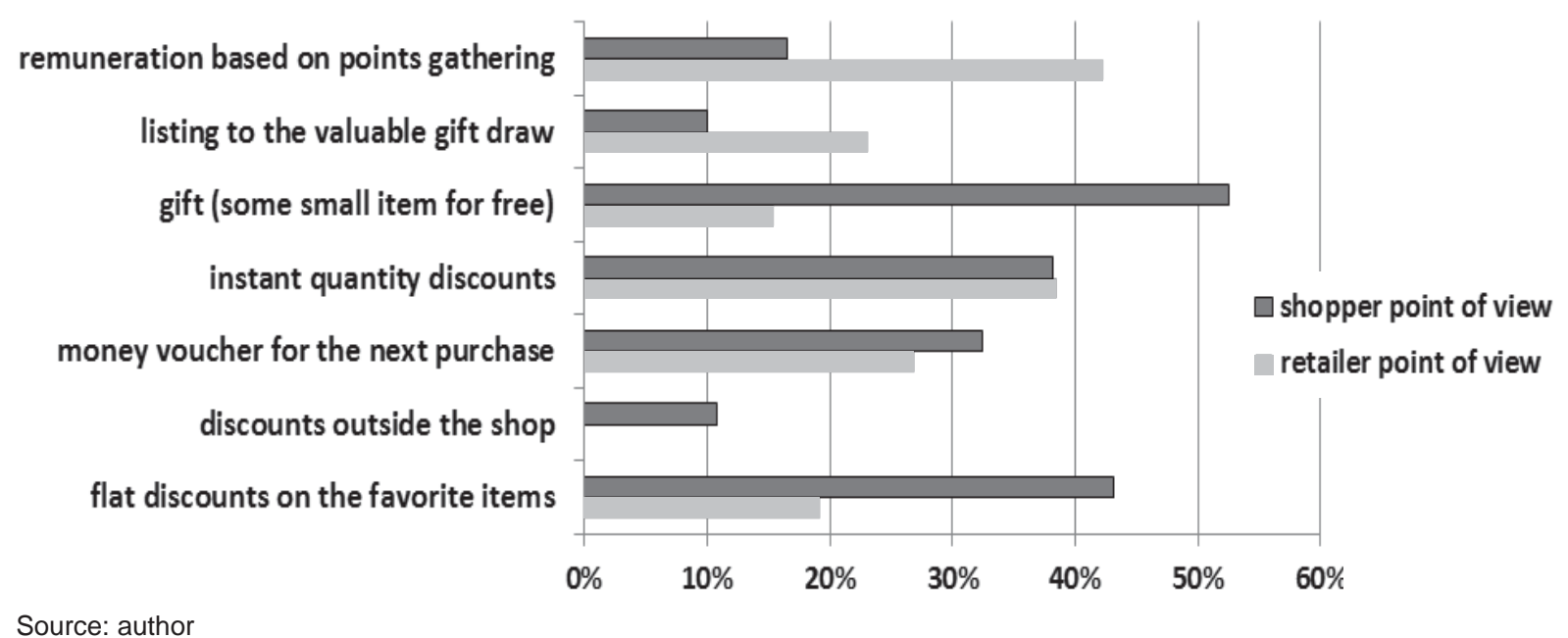

Source: author

their identification and contact information. Especially in connection with e-shops, customers are forced to think out and memorize or store a new username and password to be able to identify themselves. In many other cases, the purchase history archiving process is connected with ownership of some plastic card, which is sometimes perceived as not a very user friendly model.

The chart below shows the comparison of what loyalty benefits are communicated by the e-shop retailers to their customers on the one hand, and on the other hand, what kind of reward benefits the customers ticked as favored. As evident from the chart above, in many cases, the retailers' strategy does not meet with shoppers' wishes. Therefore, it is important to find a compromise that would work. The research shows that quantity discounts that can be applied immediately when shopping can be considered as the suitable kind of solution.

\section{Managerial Implications}

Retailers that have been running their e-shops are trying to attract consumers. One of the tools that is frequently used are loyalty programs. Customer loyalty is a very complicated process that is influenced by many aspects. Some of them can be characterized as so-called "soft" criteria. This means they can hardly be quantified and they cover such parameters like user friendliness of the e-shop application, style and way of the e-shop communication towards its customers, and many others. The key analysis of this paper concentrates on e-shop loyalty program parameters. The analysis brings the comparison of what the e-shops typically communicate as the advantages of the program with the view of e-shop customers, their wishes and ideal parameters from their point of view.

The research has also revealed a huge challenge for retailers: the majority of customers like being remunerated and participate in a loyalty scheme, but less than one-third of them have really done so. Exploiting this business potential can bring the retailers significant advantage.

Online retailers strongly tend to make customers bound with the program. Therefore, cumulating of value purchases is a typical loyalty program feature. In contrast, customers prefer instant benefits without any complicated algorithm.

A useful compromise, based on our research, can be the loyalty model when the customer is remunerated immediately and the financial volume of the discount is fixedly interconnected with the financial amount of the ongoing purchase. Such a model has the high potential to bring a competitive advantage because it meets the customers' demands and, based on the research, is not contradictory to the retailers' strategy.

\section{References}

Cook, W. A. (1996). Strive for Loyal Brands, then Loyal Consumers. Journal Of Advertising Research, 36 (6): 6-7.

Ganesh, J., Reynolds, K.E., Luckett, M., Pomirleanu, N. (2010). Online Shopper Motivations, and e-Store Attributes: An Examination of Online Patronage Behavior and Shopper Typologies. Journal of Retailing, 86 (1): 106-115.

Kooser, A. C. (2009). Online Loyalty Programs. Restaurant Business, 108 (11): 18. 
Oliver, R. L. (1999). Whence Consumer Loyalty?. Journal Of Marketing, 63 (4): 33-44.

Pilík M. (2012). On-line Shopping on B2C Markets in the Czech Republic. Journal of Competitiveness, 4 (4): 36-49.

Stříteský, V. (2013) Internet jako globální marketingové médium. In: Bačuvčík, R., aj. Globální a lokální v marketingové komunikaci. Zlín: VeRBuM

Stříteský, V. (2013). Internet jako globální marketingové médium. In R. Bačuvčík, Globální a lokální v marketingové komunikaci (p. 19-31). Zlín: Verbum.

Šipula, P. (2013). Jak nakupuje internetová populace v e-shopech. STRATEGIE.CZ, (accessed March 24, 2014), [available at: http://strategie.e15.cz/zurnal/ stem-mark-jak-nakupuje-internetova-populace-v-eshopech-980943].

Tomek, I., Stříteský, V., Tahal, R. (2013). Segmentation of Czech Consumers Based on the Attitudes Towards Money. Central European Business Review, 2 (2): 19-24.
Zhaohua, D., Yaobin, L.(2010). Understanding customer satisfaction and loyalty. International Journal of Information Management. , 30 (4): 289-300.

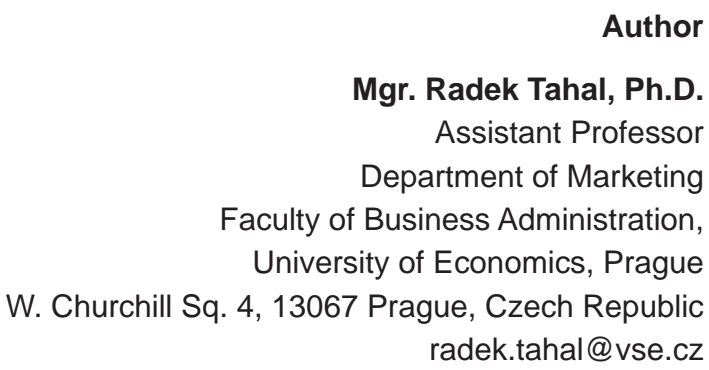

Author

Mgr. Radek Tahal, Ph.D. Assistant Professor Department of Marketing

Faculty of Business Administration, University of Economics, Prague

W. Churchill Sq. 4, 13067 Prague, Czech Republic radek.tahal@vse.cz

This study was supported from the resources for long-term conceptual research development of the University of Economics, Prague IP306012. 